\title{
The Improvement of Arabic Learning Program in Realizing the World Class University
}

\author{
Syaiful Mustofa ${ }^{1}$, Suci Ramadhanti Febriani ${ }^{2}$, Faisal Mahmoud Ibrahim ${ }^{3}$ \\ ${ }^{1}$ Arabic Education Study Program Universitas Islam Negeri Maulana Malik Ibrahim Malang, Indonesia \\ ${ }^{2}$ Arabic Education Study Program Universitas Islam Negeri Maulana Malik Ibrahim Malang, Indonesia \\ ${ }^{3}$ Postgraduate Program in Arabic Teaching University of the Holy Quran and Islamic Sciences, Sudan
}

\author{
Article History: \\ Received : October 11, 2020 \\ Revised : November 13, 2020 \\ Accepted : December 29, 2020 \\ Published : June 01, 2021
}

\section{Keywords: \\ Communication; Curriculum; Integration Learning; World Class University}

*Correspondence Address: saifulmustofa@pba.uin-malang.ac.id

\begin{abstract}
Foreign language is one of the fundamental elements in creating the world class university. To realize a world class university, the excellent Arabic language learning program is necessary to meet the needs of international communication in the internal and external environment of the campus. This study aimed to explore and analyze the Arabic language learning program at UIN Maliki Malang. The research data were obtained from the interview with campus governance and direct observation of Arabic learning program activities and the documentation of strategic planning of Arabic language learning programs to create a world class university. The interviews were conducted with 10 people of campus institution governance. The results showed that Arabic language learning program in realizing a world class university is an implementation of the university's vision which is contained in the development of an integrated curriculum and ulul albab character. The curriculum is designed in the form of a "tree of knowledge" construction. To form solid scientific roots, linguistic strengthening is needed so that its branches and its twigs are strong too. Language strengthening is manifested in the form of the Special Arabic Language Class Program (PKPBA), Ma'had al-jami'ah program and intensive training for educators and educational staff. These findings indicate that the integration of Arabic language learning programs between internal campus institutions is a measure of success in realizing a world class university. The recommendation for further research was to measure the effectiveness of each program at UIN Maliki Malang.
\end{abstract}

\section{Introduction}

Arabic learning development program has an influence on foreign language competence and skills for students and educators in communication. This is an important concern in realizing a world class university in order to support international communication skills ${ }^{1}$. As it is known that Arabic is one of the major languages in the

${ }^{1}$ E. J. Usoh et al., "Strategic Planning towards a World-Class University," IOP Conference Series: Materials Science and Engineering 306, no. 1 (2018), https://doi.org/10.1088/1757-899X/306/1/012035. 
world which is spoken by more than 200,000,000 people $^{2}$. Arabic learning development program is a pillar for scientific development and international cooperation networks as one of the requirements for a world class university. The previous research related to the development of Arabic learning programs has only achieved development in the realm of teaching materials ${ }^{3}$, intensive Arabic language program development ${ }^{4}$, development of various learning strategies, ${ }^{5}$ as well as the use of interactive learning media ${ }^{6}$, mapping of world class university indicators ${ }^{7}$. Based on previous findings, research related to Arabic language learning programs to create a world class university can be realized in order to face global competition.

The previous researches explained the role of Arabic in the development of Islamic science and civilization. Arabic has an important role in the development of science because it is the source language of knowledge, Islamic literature is written in Arabic and as the media for study ${ }^{8}$. Arabic has an important role in Islamic civilization, it is the language of unity among Muslims, the language of Arabic culture throughout the ages, the language of information technology, and the language of communication tools ${ }^{9}$. In addition, another study explained that the urgency of Arabic is very important for human life to provide enlightenment of ideas, information and thoughts in understanding Arabic texts such as Al-Qur'an, Hadith, and other classical books and to improve the faith quality ${ }^{10}$. Another study explained that the role of Arabic in understanding Islamic religious education with thinking approach to knowledge or certainty. It means that

${ }^{2}$ Sofyan Sauri, "Sejarah Perkembangan Bahasa Arab Dan Lembaga Islam," INSANCITA: Journal of Islamic Studies in Indonesia and Southeast Asia, 5, no. 1 (2020): 73-88, https://doi.org/https://doi.org/10.2121/incita-jisisea.v5i1.1332.g1159.

${ }^{3}$ Khairi Abu Syairi, "Pengembangan Bahan Ajar Bahasa Arab," Dinamika Ilmu 13, no. 1 (2013): $51-66$.

${ }^{4}$ Hikmah Uswatun Ummi and Indrya Mulyaningsih, "Penerapan Teori Pembelajaran Bahasa Arab Di IAIN Syekh Nurjati Cirebon," Journal Indonesian Language Education and Literature 1, no. 2 (2016): 207-20.

${ }^{5}$ Chen Chung Liu, Pin Ching Wang, and Shu Ju Diana Tai, “An Analysis of Student Engagement Patterns in Language Learning Facilitated by Web 2.0 Technologies," ReCALL 28, no. 2 (2016): 104-22, https://doi.org/10.1017/S095834401600001X.

${ }^{6}$ Mohammad Ahsanuddin, "Pemanfaatan CD Interaktif Untuk Pembelajaran Bahasa Arab Untuk Anak(ALA)," (2004):8.

${ }^{7}$ Muhammad Junaidi Marasabessy, "Manajemen Mutu Bertaraf World Class University (Multikasus Di Universitas Islam Negeri Maliki Malang Dan Universitas Brawijaya)" (UIN Maulana Malik Ibrahim Malang, 2016), 61.

${ }^{8}$ Muhsin Muis, "Bahasa Arab Di Era Digital: Eksistensi Dan Implikasi Terhadap Penguatan Ekonomi Keumatan," Jurnal Al-Fathin 3, no. 1 (2020): 64.

9 Muhbib Abdul Wahab, "Peran Bahasa Arab Dalam Pengembangan Ilmu Dan Peradaban Islam," Arabiyaat 1, no. 1 (2014): 3.

${ }^{10}$ Asna Andriyani, "Urgensi Pembelajaran Bahasa Arab Dalam Pendidikan Islam," Ta'alum 3, no. 1 (2015): 49-52 
Arabic has a major influence on the understanding of religious science, especially the material of Islamic Education Study Program (PAI) in university because many terms are written in Arabic, so, the influence reaches $61.7 \%^{11}$. Based on previous findings, special studies are still needed related to superior programs implemented in order to improve the competence of Arabic as a reputable institution to prepare a world class university.

In preparing a world class university, excellent program which is based on skills is needed. As the development of the Arabic language development program, it can encourage the skills of students and campus stakeholders to communicate by using foreign languages. On that basis, this research serves to describe and explore Arabic language development programs in realizing a world class university.

To achieve the aims of research, case study design was used to reveal the phenomenon of the Arabic language learning program at UIN Maulana Malik Ibrahim Malang. Based on the previous explanation, this research is expected to contribute to each university to develop superior programs in the development of Arabic learning programs specifically. This is necessary to produce proficient graduates in foreign languages and in facing human resource competition globally. Based on the above explanation, this study aims to explore and analyze the development of Arabic language programs in realizing a world class university at UIN Maulana Malik Ibrahim Malang.

\section{Method}

Qualitative approach was used to analyze the phenomenon of the development of Arabic language learning in realizing a world class university. The phenomena that exist in the research location holistically was examined and described in a descriptive manner in the form of words and language context. The method design was a case study at UIN Maulana Malik Ibrahim Malang, which is one of the campuses leading to a world class university. This research focused on internal campus institutions that carry out Arabic language development programs such as PKPBA and the Language Development Center.

Data collection techniques were interviews, observation and documentation. Interviews were conducted with the chancellor, former chancellor, vice chancellor, chairman of the LPM, chairman of LP2M and other resource persons who have policies related to the themes discussed. The selected informants are based on the track records

11 Miftah Wangsadanureja, "Peran Bahasa Arab Dalam Memahami Pendidikan Agama Islam Dengan Pendekatan Berfikir Knowledge or Certainty," Jurnal Pendidikan Islam 8, no. 1 (2017): 33. 
and experiences of the campus founders and institutional managers who are directly related to the development of Arabic learning programs at UIN Maulana Malik Ibrahim Malang. Observations were made on activity facilities, academic services and other facilities with international standards. The documentation that became the data source is accreditation, journals, research and other academic activities with international standard. The validity of the data was carried out through expert, peers and Focus Group Discussions (FGD). The research technique which had been used in collecting data such as compiling a list of interview questions, the object of the study of observed observations and a list of documentation lists are needed to strengthen the data.

The data analysis technique used refers to Milles and Hubberman's theory with data triangulation techniques ${ }^{12}$. Triangulation was carried out to match the data obtained through interviews, observation and documentation. The stages of data analysis can be seen in the following figure.

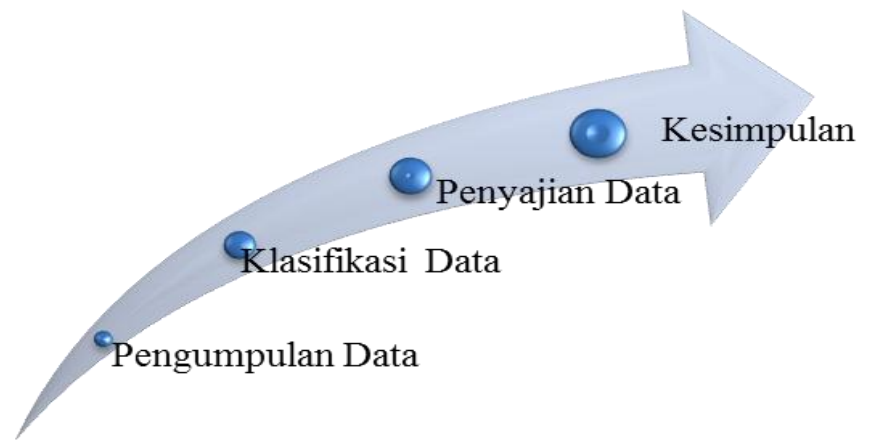

Figure 1. Data Analysis Technique

Figure 1 explains; first, record all findings of phenomena in the field either through observation, interviews or documentation in the form of field notes. The results of this interview will be transcribed verbatim. Second, reviewing field notes and separating important and unimportant data. Third, describe the data for further analysis. Fourth, make a final analysis to draw conclusions.

\section{Result and Discussion}

One of the programs that can provide opportunities for universities to become world class universities is to develop foreign language learning. UIN Maulana Malik Ibrahim Malang has developed a foreign language learning process, especially Arabic for

${ }^{12}$ Robert K. Yin, "Case Study Research Design and Methods, Third Edition, Applied Social Research Methods Series, Vol 5 2002.Pdf," 2003. 
domestic students and foreign students. It aims to prepare quality human resources in terms of both educators and educational staff. Arabic development program is one way to create a competitive world class university in the global higher education market ${ }^{13}$. This serves to enhance the university's reputation and allows it to play an active role in the global market. The efforts to develop a world class university in teaching and learning can be seen through the following aspects:

\section{Curriculum Integration}

Curriculum development in UIN Maulana Malik Ibrahim Malang is based on integration. Integration between science and religion, curriculum construction is "pohon ilmu" (tree of knowledge"). See figure 3 below:

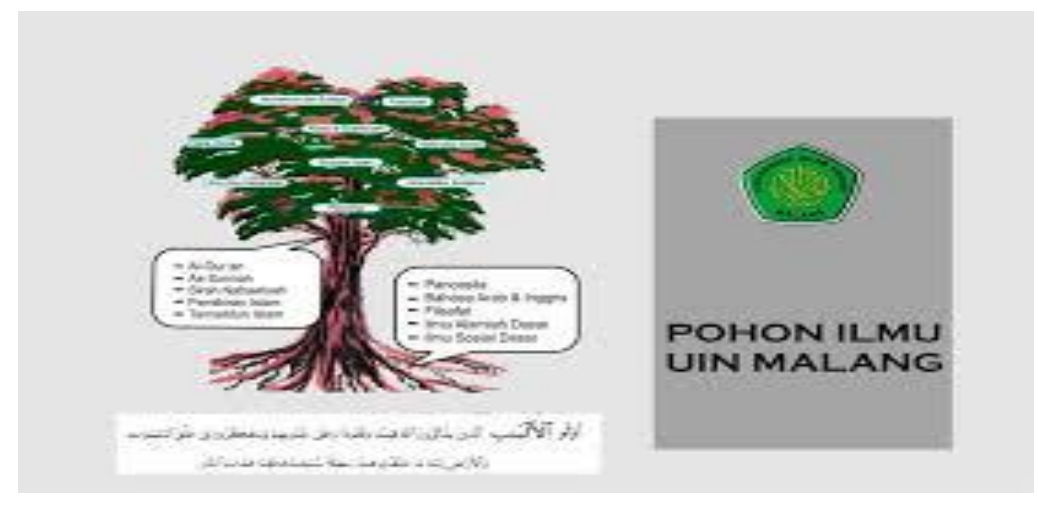

Figure 2. Construction of Scientific Integration

Figure 2 describes the construction of a knowledge tree that must be built through strong roots, one of which is foreign language. With strong foreign language skills, graduates are expected to be able to gather information and respond to changing times and be able to compete globally according to their respective scientific capacities. As informant R1 stated that: "Proses integrasi ilmu perlu menjadi dasar utama dalam pengembangan pengetahuan di UIN Malang. Melalui filosofi pohon ilmu yang dibagun, diharapkan lulusan dibekali ilmu pengetahuan yang holistik sehingga menjadi insan kamil yang mampu merespon setiap perkembangan zaman dan kebutuhan masyarakat dunia”. (Interview Is, 2020)

Based on this statement, UIN Maulana Malik Ibrahim Malang has developed the integration of religion and science with a strong mastery of foreign languages. This form of integration is reflected in the philosophy of the tree of knowledge, when the roots of

${ }^{13}$ Akhiril Pane, "Urgensi Bahasa Arab Sebagai Alat Komunikasi Agama Islam" Komunikologi," KOMUNIKOLOGI 2, no. 1 (2018): 77.

57 | Jurnal Al Bayan: Jurnal Jurusan Pendidikan Bahasa Arab, 13 (1): 53-72 (2021) 
the tree are firmly formed, the trunks, branches and twigs will be strong. Mastery of foreign languages, especially Arabic, is a major requirement in forming a body of knowledge so that scientific roots become strong. The scientific integration can provide great opportunities and opportunities for graduates to have varied skills ${ }^{14}$. In addition, the integration of science can provide students with a continuous learning experience, not limiting one scientific field ${ }^{15}$.

Furthermore, to strengthen the integration of science and answer the demands of the world community, new Faculties and Study Programs were opened, namely Faculty of Science Technology and School of Medicine \& Health Sciences. The Faculty of Science and Technology includes the study programs of Physics, Chemistry, Mathematics, Biology, Architectural Engineering and Information Engineering. Meanwhile, the Faculty of Medicine \& Health Sciences covers the Medical and Pharmacy study programs. As informant R2 revealed that: "Salah satu pengembangan UIN Maulana Malik Ibrahim Malang ialah membuka Fakultas Sains Teknologi dan Fakultas Kedokteran \& Ilmu Kesehatan bertujuan untuk merespon kebutuhan masyarakat tentang output lulusan yang berkarakter ulul albab, kompetitif, dinamis dan cepat merespon kebutuhan zaman.” (Interview Is, 2020).

This statement illustrates that the development of an integration-based curriculum with ulul albab character is a new innovation breakthrough to answer the demands of the times. The integration curriculum is developed through a combination of religious and scientific sciences. The ulul albab character is developed through the practice of noble Islamic values as stated in the university's vision "to become an Islamic university that is superior, trusted, competitive, and has an international reputation". Through this vision, each learning process is internalized through four pillars, namely; standardization of ulul albab values, internalization of ulul albab values, certainty of individual beliefs and behavior based on ulul albab values, and caring for these values so that they become culture.

Through the efforts and high consistency in the integration of curriculum and ulul albab character, UIN Maulana Malik Ibrahim Malang has made an achievement as the

${ }^{14}$ Basma Ahmad Sedki Dajani, "Teaching Arabic Language: Towards a New Beginning That Stimulates Creativity," Procedia - Social and Behavioral Sciences 192, no.24 (2015): 758-763, https://doi.org/10.1016/j.sbspro.2015.06.086. 
third largest university in PTKIN (Webo Metric version) from the aspect of journal citation by the international community in 2013. In the same year, it received "A" for its accreditation. In 2019, it continued to maintain "A" accreditation from BAN-PT with 166/SK/BAN-PT/Akred/PT/IV/2019. In 2015, it was internationally accredited with ISO 9001: 2015 until December 2020. The ISO certificate with number 1386Q is a proof that this university is in earnest to realize a world class university.

\section{Special Arabic Language Class Program (PKPBA)}

With the curriculum which based on integration and ulul albab character, language development is the priority. Language is a tool of communication among human beings and it plays an important role in the exchange of global information. UIN Maulana Malik Ibrahim Malang developed intensive Arabic through the Special Arabic Language Learning Program (PKPBA) under the Language Development Center unit. The intensive Arabic program is a compulsory subject for new students of all faculties, learning time is from Monday to Friday from 14.00 - 17.00 for one year or two semesters. Each semester must take 6 credits including 1 credit of listening skills, 1 credit of speaking skills, 2 credits of reading skills, and 2 credits of writing skills. Intensive programs in language learning can provide opportunities and opportunities for students to improve language skills ${ }^{16}$.

The aim of the intensive Arabic program is to provide foreign language competencies for students to be able to study various sciences from various literatures and be able to communicate with the international community. As informant R3 stated that: "Program bahasa Arab dan bahasa Inggris intensif merupakan matakuliah wajib untuk tujuh fakultas yang ada. Mahasiswa harus mampu menguasai kompetensi dwi bahasa ini dan wajib lulus, jika belum lulus program intensif ini, maka mahasiswa belum bisa mengambil matakuliah di tingkat selanjutnya." (Interview M1, 2020). This statement illustrates the importance of mastering foreign languages so that the Chancellor takes policies outside the standards of the education system, with a weight of 12 credits,

${ }^{15}$ Carmen M. Amerstorfer, "The Dynamism of Strategic Learning: Complexity Theory in Strategic L2 Development," Studies in Second Language Learning and Teaching 10, no. 1 (2020): 21-44, https://doi.org/10.14746/ssllt.2020.10.1.2.

${ }^{16}$ Ilinawati Ilinawati and Sijono Sijono, "Improving Students' Speaking Motivation Using Mingle Music Technique," Journal of English Educational Study (JEES) 3, no. 1 (2020): 1-9, https://doi.org/10.31932/jees.v3i1.569. 
students must take intensive lectures every day for one year. Hence, the time intensity encourages the development of students' language production ${ }^{17}$.

This intensive Arabic language program has been running for 24 years since it was started in 1997, learning activity starts at 14.00 - 20.00. However, in 2017 the learning shifted from 14.00 - 17.00 WIB. Before joining this program, students are required to take a placement test, which is an initial test to measure academic ability. This test is important to do to measure their competence at the beginner, intermediate or high level. Competency mapping also helps to make lecturers easier to develop strategies that are suitable for students ${ }^{18}$. Al-Arabiyah Li al-Nasyi'in book is used in the intensive Arabic language program. In 2003, al-Arabiyah Baina Yadaika book was used, these two books were published by the Kingdom of Saudi Arabia. In 2017, al'Arabiyah Lil Hayah was used, it was a textbook compiled and published by PKPBA lecturers..

\section{Human Resources Development}

The development of Arabic programs is not only for students, but also for Arabic teaching staff (lecturers) and education staff (employees) in the form of training twice a week. The human resource development program is training for educators and education staff in all faculties, guided by Arabic and English lecturers at the Language Development Center (P2B) unit to practice their language skills, the competency for educators is also important to be improved ${ }^{19}$. One of the objectives of the foreign language program is to improve foreign language skills for all educators and education staff so that they are able to help the students optimally ${ }^{20}$. The following figure is material used in the training:

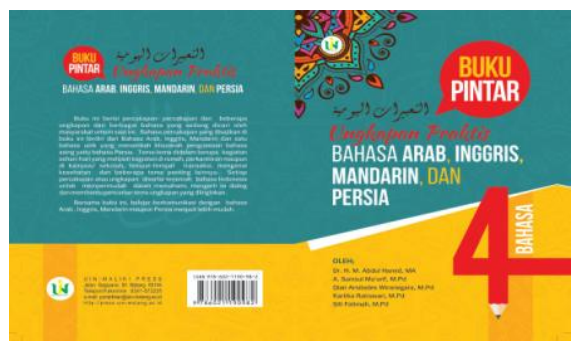

Figure 3. Teaching Material for Human Resources Development Training

\footnotetext{
17 Olga Muranova, "New Media and Perennial Problems in Foreign Language Learning and Teaching," CALICO Journal 34, no. 3 (2016): 380-83, https://doi.org/10.1558/cj.32173.

${ }^{18}$ Arifka Mahmudi et al., "Classroom Management and Arabic Learning Process Based On Multiple Intelligences", Arabiyât. 6, no. 2 (2019): 222-37.

${ }^{19}$ Lorena Manaj Sadiku, "The Importance of Four Skills Reading, Speaking, Writing, Listening in a Lesson Hour," European Journal of Language and Literature 1, no. 1 (2015): 29, https://doi.org/10.26417/ejls.v1i1.p29-31.

${ }^{20}$ Qiang Huang, "Learners' Perceptions of Blended Learning and the Roles and Interaction of F2f and Online Learning.," ORTESOL Journal 33, no. 2013 (2016): 14-33.
} 
Figure 3 explains that the textbooks used for training lecturers and education staffs are designed to be easy and enjoyable, so the learning process can be done as expected. It is hoped that the entire community will be able to use Arabic and English properly so that they can be used in the learning process for students. The informant R4 said: "Kegiatan pelatihan bahasa Arab dan bahasa Inggris sangat dibutuhkan untuk pengembangan sumber daya manusia di kampus ini. Pelatihan bahasa Arab dilaksanakan satu minggu dua kali pertemuan, sedangkan bahasa Inggris satu minggu satu kali pada masing-masing fakultas”. (Interview Za, 2020).

Based on this statement, it can be described that Arabic and English training for lecturers and education staff in each faculty runs intensively and it is necessary for learning process and campus community services. This training uses the direct method by practicing language directly in their daily life. This is done to improve human resources who are superior and have global competitiveness in the context of realizing a world class university. The form of program evaluation is carried out by the head of the unit or each faculty in coordination with the Language Development Center and the results of the evaluation are submitted to the Rector for follow-up. Evaluation is to determine the achievement of the planned targets ${ }^{21}$.

\section{Ma'had al-Jami'ah}

Ma'had al-Jami'ah has been established since 2001 until now, he is 20 years old. Ma'had al-Jami'ah is a one-year compulsory program for new students of all faculties to live in campus dormitories. The purpose of establishing Ma'had Al-Jami'ah is to support the vision, mission and university programs based on integration andulul albab character, and forming a language environment. The integration that is being developed is a combination of religious knowledge and science. The ulul albab character is formed through intensive recitation activities such as studying Al-Qur'an al-Karim, Kitab Kuning (Yellow Book), and practicing language in the morning (shabah al-lughah).

Character building starts from the first meeting in their class, so that they have good morals, love each other, love their homeland, are disciplined, honest and responsible. Besides that, the existence of Ma'had al-Jami'ah is very important to form a language environment in order to create a language environment. It is explained that the language environment plays a role in increasing the capacity of language skills

\footnotetext{
${ }^{21}$ Suci Ramadhanti Febriani, "The Evaluation of Arabic Learning Based on Multiple Intelligences Classroom," International Journal of Arabic Language Teaching 2, no. 2 (2020): 131-48.

61 | Jurnal Al Bayan: Jurnal Jurusan Pendidikan Bahasa Arab, 13 (1): 53-72 (2021)
} 
naturally ${ }^{22}$. This language environment synergizes with the development of Arabic and English language programs at the Language Development Center (P2B) unit. These two large units, namely the Arabic and English language programs at the Language Development Center (P2B) and Ma'had al-Jami'ah, are the university's distinctions and the main pillars in supporting the vision, mission and big ideals towards a world class university.

As one of the university's distinctions, the Ma'had Al-Jami'ah program is carried out in an integrated manner with the faculty to support the improvement of student academic competence. Form of integration in programming and academic system (SIAKAD) automatically. For example, if there is a study material that does not pass, the system will automatically record it in red and will show the Islamic subjects that cannot be taken in the next semester. As informant R5 said that; "Semua program di ma'had aljami'ah terintegrasi dengan program akademik di fakultas, sehingga ketika ada mahasiswa yang tidak lulus ujian akademik pada program ma'had, maka mahasiswa tersebut tidak dapat memprogram studi pada semester berikutnya, seperti matakuliah fiqih, studi al-Qur'an, studi Hadits, teologi dan tasawwuf." (Interview Mz, 2020)

This statement describes that the sinergy between the faculty and Ma'had aljami'ah are quite strong so that all the program activities are integrated well. The existence of this program really supports the academic of faculty. In general, there are two programs in Ma'had, those are increasing spirituality and increasing academic competence. Spiritual enhancements are such as doing prayer in a flock, $d z i k r$, reciting aurad mu'tabarah, reciting ratibul haddad in the evening and reciting wirdul lathif in the morning. Meanwhile, the improvement of academic competence is through the study of the Al-Qur'an, the study of Kitab Kuning (Yellow Book), practicing language in the morning (shabah al-lughah).

For the study of Al-Qur'an, every student must be able to read Al-Qur'an fluently and correctly. If their al-Qur'an recitation is not fluent, they will enter the tahsin group. But, If they have recited it fluently and correctly, they will be directed to the tahfidz group. Meanwhile, the study of Kitab Kuning (Yellow Book) is done every night after praying Isya, and the material is Fiqih At-tadzhib book, Qomi 'At-tughyan book for the

\footnotetext{
${ }^{22}$ Agus Shaleh, "Kendala Dan Solusi Kreatif Mahasiswa Dalam Belajar Bahasa, Sastra Dan Budaya Arab: Lingkungan Behavioristik Dalam Berkomunakasi Bahasa Arab Di STAI Syaichona Moh. Cholil Bangkalan," in Seminar Nasional Bahasa Arab Mahasiswa I Tahun 2017 (2017): 386.
} 
interpretation, and Bulughul Maram for studying Hadith. For shabah al-lughah (practicing language in the morning) activity is done after reciting aurad mu'tabarah in the morning at 05.00-06.00 WIB. The goal is to train students' language actively by adding vocabulary every day, arranging sentences in the form of jumlah mufidah, writing training based on the material. Theory of language said that the process of habituation is important in order to form a language environment properly and will accelerate the acquisition of the target language ${ }^{23}$.

Shabah al-lughah activities are routinely done in the campus environment such as at the mosque, field, campus parks, mabna hallways and other supported places. As informant R6 said: “Kegiatan shabah al-lughah dilaksanakan di pagi hari menyebar di berbagai tempat, supaya mahasiswa tidak bosan dengan lingkungan mabna dan tidak mengantuk ketika proses belajar. Memang berat awalnya, tapi karena sudah terbiasa, maka hal ini menjadi rutinitas positif bagi kami untuk meningkatkan kemampuan bahasa asing." (Interview Mz, 2020). Based on this statement, the activities of shabah al-lughah are not tied to only one place, the importan thing is the activities can be done happily and pleasantly. When game strategies, demonstrations, role playing, discussions and with the media of songs are used in the teaching and learning process, the students will feel happy and excited. In the learning theory, it is said that if a learning strategy and method are varied, it will be able to encourage student creativity and critical thinking ${ }^{24}$.

As informant R7 said that: "Pembelajaran dalam kegiatan shabah al-lughah menggunakan berbagai macam strategi dan metode, tujuannya untuk menciptakan suasana belajar aktif, kreatif, menggembirakan dan tidak membosankan, karena kegiatan ini dilakukan secara rutin setiap pagi hari.” (Interview Mz, 2020). This statement illustrates that the creation of a pleasant and joyful learning atmosphere must be done in order to create a lively learning environment, because the learning environment can affect student motivation and output in learning. Psychological theory stated that a healthy and pleasant learning environment will encourage the learning

${ }^{23}$ Uril Bahruddin and Suci Ramadhanti Febriani, "Student' s Perceptions of Arabic Online Learning during COVID-19 Emergency," Journal for the Education of Gifted Young Scientists 8, no. 4 (2020): 1483-92, https://doi.org/http://dx.doi.org/10.17478/jegys.760735.

24 Matthew Toh Loy Lim et al., "An Alternative Approach to Teaching: Implementing a Cooperative Learning Strategy Students Team Achievement Division at the Junior College Level," Advanced Science Letters 22, no. 5-6 (2016): 1725-29, https://doi.org/10.1166/asl.2016.6748. 
motivation and will have an impact on the success of learning ${ }^{25}$.

This psychological theory is also supported by the learning theory which said that the diversity of strategies and methods used in a lesson will provide more motivation to students and will encourage the creation of fun and enjoyable learning ${ }^{26}$. Environmental factors have an influence on the language productive abilities of students ${ }^{27}$. Some of these factors can be seen in shabah al-lughah joyful atmosphere which can be seen in Figure 4 below:

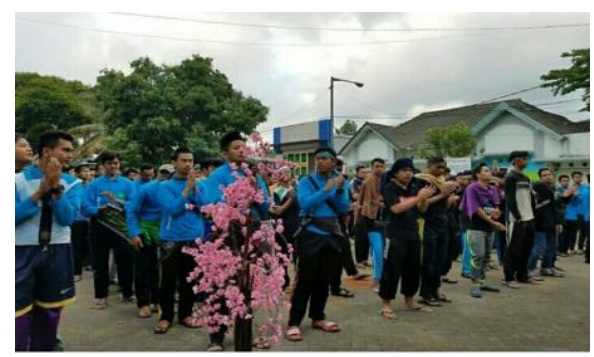

Figure 4. Activity of Shabah al- Lughah

Figure 4 provides an explanation that the learning atmosphere in shabah allughah activities is always carried out with full of joy among students, a strong emotional bond are built even though they are in different faculties. The diversity of backgrounds also encourages the transfer of knowledge between them. Many students majoring in Arabic Language Education have a strong knowledge of information and technology because in their classmates are majoring in Information and Technology, or vice versa. As language skills cannot be separated from the role of technology ${ }^{28}$. This language environment can be formed through an indoor or outdoor environment ${ }^{29}$. So, the language learning process and language acquisition can be integrated with each other. In addition, efforts can be made to increase the intensity of seminars, conferences and

${ }^{25}$ Alan V. Brown, “Students' and Teachers' Perceptions of Effective Foreign Language Teaching: A Comparison of Ideals," Modern Language Journal 93, no. 1 (2009): 46-60, https://doi.org/10.1111/j.15404781.2009.00827.x.

${ }^{26}$ Huang, "Learners' Perceptions of Blended Learning and the Roles and Interaction of F2f and Online Learning," ORTESOL Journal, vol. 33 no.2 (2013):14-33.

27 J. Scott Payne, "Developing L2 Productive Language Skills Online and the Strategic Use of Instructional Tools," Foreign Language Annals, no. May (2020): 1-7, https://doi.org/10.1111/flan.12457.

${ }^{28}$ Suci Ramadhanti Febriani and Anasruddin Anasruddin, "Technology for Four Skills Arabic in the Era Emergency of Covid-19 in Indonesia," Ta'lim Al-'Arabiyyah: Jurnal Pendidikan Bahasa Arab \& Kebahasaaraban 4, no. 1 (2020): 1-11, https://doi.org/10.15575/jpba.v4i1.8221.

${ }^{29}$ Muhammad Aswad, "The Effectiveness English Camp (A Model in Learning English as the Second Language)," ASEAN/Asian Academic Society International Conference Proceeding Series, 2017, 234-39. 
activities in Arabic ${ }^{30}$.

A strong emotional bond between them also cannot be separated from the role of mentor. The mentor helps to provide directions on an ongoing basis so that the learning process runs optimally ${ }^{31}$. In addition, the mentor also plans and evaluates the learning process $^{32}$. The mentor in Ma'had of UIN Maulana Malik Ibrahim Malang or commonly known as musyrif helps to guide every male student activity, and musyrifah as the female mentor helps to guide every female student activity. These mentors are their senior who have superior academic competency and have been through strict selection. The role of the mentors is important in every activity because they are academically responsible for the students he supervises. The mentors must always coordinate with the murabby (educator) of master and doctoral students. Murabby is responsible for carrying out activities smoothly according to the standards set by the community council (masyayikh) or the person in charge or Kyai. They coordinate with university governance to synergize programs so that they do not overlap.

The musyrif and musyrifah are always provided with training and workshops once a semester to improve their competence. As in Figure 5 below:

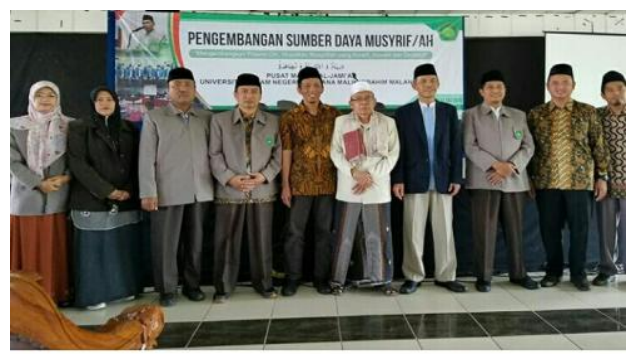

Figure 5. Council of Kyai (Clerics) in Ma'had al-Jami'ah with the Fourth Vice Chancellor

Figure 5 describes affirmation of the synergy between university governance and the council of Kyai, an activity of enhancing professional human resources for mentors. Professionalism is formed through a balance of intellectual and emotional intelligence. Psychological theory stated that the balance of intellectual and emotional intelligence

${ }^{30}$ Yuangga Kurnia Yahya, "Usaha Bahasa Arab Dalam Menghadapi Era Globalisasi," Konferensi Nasional Bahasa Arab 3, 2017, 38-48.

31 Aleidine J. Moeller and Theresa Catalano, "Foreign Language Teaching and Learning," International Encyclopedia of the Social \& Behavioral Sciences: Second Edition, 2015, 327-32, https://doi.org/10.1016/B978-0-08-097086-8.92082-8.

32 Ayse Taskiran, Eylem Koral Gumusoglu, and Belgin Aydin, "Fostering Foreign Language Learning with Twitter: Reflections from English Learners," Turkish Online Journal of Distance Education 19, no. 1 (2018): 100-116, https://doi.org/10.17718/tojde.382734. 
will encourage someone to always be good, be inferior and not be arrogant ${ }^{33}$.

Apart from shabah al-lughah program, to improve the quality of Arabic and English, students are provided with extracurricular activities, namely Khitobah and Qira'ah. Khitobah is the process of producing Arabic activities through the delivery of lecture content in a contextual manner based on the development of the latest issues. Contextual issues can provide an actual learning experience for students ${ }^{34}$. Meanwhile, Qira'ah is in the form of reading and understanding Kitab Kuning (Yellow Book), as well as being trained in reading news items through mass media and social media. This activity can help to improve the quality of spoken language and reading comprehension and can build their self-confidence when speaks Arabic in front of public ${ }^{35}$. It was also found that routine and habituation were the determining factors for students' success in mastering the language ${ }^{36}$. As habituation is an effective way to train receptive and productive language acquisition ${ }^{37}$.

This was obtained through informant R8 who revealed that: "Setiap mahasiswa diberikan bekal untuk mengikuti ekstrakurikuler seperti qira'ah dan khitobah dengan harapan untuk menumbuhkan dan memperkuat percaya diri mahasiswa ketika berkomunikasi dengan orang arab atau penutur asli" (Interview Mz, 2020). This statement illustrates that through extracurricular activities, students are expected to have high competence in order to be able to communicate with native speakers and be able to read Kitab Kuning (Yellow Book), get information from Arabic writing in mass media or on social media. As extracurricular activities can be held indoors or outdoors ${ }^{38}$. Various

33 Charles Kivunja, "Innovative Methodologies for 21st Century Learning, Teaching and Assessment: A Convenience Sampling Investigation into the Use of Social Media Technologies in Higher Education," International Journal of Higher Education 4, no. 2 (2015): 1-26, https://doi.org/10.5430/ijhe.v4n2p1.

${ }^{34}$ Samiril Taurus Tamaji, "Pembelajaran Bahasa Arab Dengan Pendekatan Contekstual Teacing and Learning (CTL)," in Universitas Negeri Malang (Malang: Universitas Negeri Malang, 2019), 46.

35 Sooho Song, "Second Language Acquisition as a Mode-Switching Process: An Empirical Analysis of Korean Learners of English," Second Language Acquisition as a Mode-Switching Process: An Empirical Analysis of Korean Learners of English, 2017, 1-151, https://doi.org/10.1057/978-1-137-524362.

${ }^{36}$ Uril Bahruddin and Suci Ramadhanti, "Implementation of Krashen 's Theory in Language Acquisition," International Journal of Innovation, Creativity and Change, 13, no. 8 (2020): 31-821.

${ }^{37}$ Rana Abid Thyab, "Mother-Tongue Interference in the Acquisition of English Articles by L1 Arabic Students," Journal of Education and Practice 7, no. 3 (2016): 1-4, https://files.eric.ed.gov/fulltext/EJ1089791.pdf.

38 Candra Hadi Asmara, "EFL Learners' Perception toward an Outdoor Learning Program," International Journal of Education and Literacy Studies 4, no. 2 (2016); 74, https://doi.org/10.7575/aiac.ijels.v.4n.2p.74. 
activities also have a positive impact on student motivation ${ }^{39}$. The process of carrying out these activities can provide a diverse learning atmosphere so that it can encourage creativity for students and lecturers ${ }^{40}$.

The description above shows the seriousness of the university governance together with the academic community in realizing a world class university by preparing human resources, curriculum, activity units, infrastructure, academic services, and other supporting facilities. Based on data in the field, this study shows how strong the role of Arabic is in realizing a world class university. Hence, the indicators of a world class university have been achieved through the indicators of developing Arabic language learning with the superior programs implemented. In every internal institution of university, Arabic learning program plays a major role in the realization of a world class university. As stated, one of the indicators in a world class university is the ability of human resources that is relevant to global needs ${ }^{41}$. It is revealed that as much as $20 \%$ of the contribution of superior Human Resources is a point for the relations of UIN Maulana Malik Ibrahim Malang in realizing a world class university ${ }^{42}$.

Through the data presented, the management of the learning program is also integrated with all internal institutions in terms of managing time allocation, improving the quality and competence of lecturers and supporting facilities. This has become a measure of the success of UIN Maulana Malik Ibrahim Malang in realizing a world class university. The statement also explained that a world class university can provide opportunities for graduates to compete in the global realm ${ }^{43}$. Hence, the management of the programs in the world class university standards is absolutely necessary ${ }^{44}$. With these indicators, the programs in UIN Maulana Malik Ibrahim Malang provide the

${ }^{39}$ Judith Giering and Hope Fitzgerald, "The Language Commons: An Innovative Space Supporting Second Language Acquisition," Journal of Teaching and Learning with Technology 8, no. 1 (2019): 3341, https://doi.org/10.14434/jotlt.v8i1.26741.

${ }^{40}$ Carol Griffiths and Rebecca L. Oxford, "The Twenty-First Century Landscape of Language Learning Strategies: Introduction to This Special Issue," System 43, no. 1 (2014): 1-10, https://doi.org/10.1016/j.system.2013.12.009.

41 Dienda Arum Pratiwi, Bambang Purwanggono, and Arfan Bakhtiar, "Kriteria World Class University Qs World Rankings,” Industrial Engineering Online Journal 6, no. 1 (2017); 1.

42 Mastuki, "World Class University: Obsesi Atau Mimpi?" (Jakarta, 2015), http://diktis.kemenag.go.id/NEW/index.php?berita=detil\&jenis=artikel\&jd=498\#.X0h_F9IzbMy, Diakses 28 September 2020, pukul 18.30.

${ }^{43}$ Michael Shattock, "The 'World Class' University and International Ranking Systems: What Are the Policy Implications for Governments and Institutions?," Policy Reviews in Higher Education 1, no. 1 (2017): 4-21, https://doi.org/10.1080/23322969.2016.1236669. 
opportunities in Arabic learning. The students of UIN Maulana Malik Ibrahim Malang also come from 32 countries with different backgrounds. With the program of Arabic learning, it is hoped that it can become a pillar of international communication in realizing UIN Maulana Malik Ibrahim Malang into a world class university campus.

\section{Conclusion}

This research revealed the Arabic language learning development program in order to create a world class university by the reinforcement of the teaching pillars. In the teaching aspect, an Arabic language learning program has been developed based on the university's vision which is implemented through an integration-based curriculum with ulul albab characteristics, strengthening language as a scientific root. The development of an integration-based curriculum is designed in the form of a "tree of knowledge" construction that combines religious and scientific knowledge. In the construction of the tree of knowledge, the reinforcement of language as a strong tree root is the main pillar in the development of knowledge. This reinforcement of language is manifested in the Arabic Language Special Class Program (PKPBA) and Ma'had al-Jami'ah. The findings of this study indicate that Arabic language learning system which is integrated between internal institutions at UIN Maulana Malik Ibrahim Malang provides encouragement to create a world class university. Based on this research, it is hoped that further research will be carried out to test the effectiveness of each Arabic learning development program with more varied research methods and more complex research objects.

\section{Acknowledgment}

Researchers would like to thank the Project Management Unit (PMU) The Development of UIN Maulana Malik Ibrahim Malang Phase II East Java project with LP2M in 2020 who have supported the implementation of this research.

\section{References}

Abdul Wahab, Muhbib. "Peran Bahasa Arab Dalam Pengembangan Ilmu Dan Peradaban Islam." Arabiyaat 1, no. https://doi.org/http://journal.uinjkt.ac.id/index.php/arabiyat/article/view/1127.

${ }^{44}$ Linda Setiawati, "EFEKTIVITAS PENGEMBANGAN MANAJEMEN PENDIDIKAN TINGGI (Studi Pada Perguruan Tinggi Negeri Di Jawa Barat Menuju World Class University)," Penelitian Pendidikan 12, no. 2 (2012): 1-15, https://doi.org/10.1245/s10434-014-4122-7. 
Abid Thyab, Rana. "Mother-Tongue Interference in the Acquisition of English Articles by L1 Arabic Students." Journal of Education and Practice 7, no. 3 (2016): 1-4. https://files.eric.ed.gov/fulltext/EJ1089791.pdf.

Ahsanuddin, Mohammad. "Pemanfaatan CD Interaktif Untuk Pembelajaran Bahasa Arab Untuk Anak(ALA)," 2004.

Amerstorfer, Carmen M. "The Dynamism of Strategic Learning: Complexity Theory in Strategic L2 Development." Studies in Second Language Learning and Teaching 10, no. 1 (2020): 21-44. https://doi.org/10.14746/ssllt.2020.10.1.2.

Andriyani, Asna. "Urgensi Pembelajaran Bahasa Arab Dalam Pendidikan Islam." Ta'alum 3, no. 1 (2015).

Asmara, Candra Hadi. "EFL Learners' Perception toward an Outdoor Learning Program." International Journal of Education and Literacy Studies 4, no. 2 (2016). https://doi.org/10.7575/aiac.ijels.v.4n.2p.74.

Aswad, Muhammad. “The Effectiveness English Camp (A Model in Learning English as the Second Language)." ASEAN/Asian Academic Society International Conference Proceeding Series, 2017, 234-39. https://www.researchgate.net/publication/323545176_The_Effectiveness_of_Engli sh_CampA_Model_in_Learning_English_as_The_Second_Language.

Bahruddin, Uril, Febriani, Suci Ramadhanti. "Implementation of Krashen's Theory in Language Acquisition Stephen". International Journal of Innovation, Creativity and Change, 13, no. 8 (2020): 821-31.

Bahruddin, Uril, and Suci Ramadhanti Febriani. "Student' s Perceptions of Arabic Online Learning during COVID-19 Emergency." Journal for the Education of Gifted Young Scientists 8, no. 4 (2020): 1483-92. https://doi.org/http://dx.doi.org/10.17478/jegys.760735.

Brown, Alan V. 'Students' and Teachers' Perceptions of Effective Foreign Language Teaching: A Comparison of Ideals." Modern Language Journal 93, no. 1 (2009): 46-60. https://doi.org/10.1111/j.1540-4781.2009.00827.x.

Dajani, Basma Ahmad Sedki. "Teaching Arabic Language: Towards a New Beginning That Stimulates Creativity." Procedia - Social and Behavioral Sciences, 2015. https://doi.org/10.1016/j.sbspro.2015.06.086.

Febriani, Suci Ramadhanti. "The Evaluation of Arabic Learning Based on Multiple Intelligences Classroom." International Journal of Arabic Language Teaching 2, no. 2 (2020): 131-48.

Febriani, Suci Ramadhanti, and Anasruddin Anasruddin. "Technology for Four Skills Arabic in the Era Emergency of Covid-19 in Indonesia." Ta'lim Al-'Arabiyyah: Jurnal Pendidikan Bahasa Arab \& Kebahasaaraban 4, no. 1 (2020): 1-11. https://doi.org/10.15575/jpba.v4i1.8221. 
Giering, Judith, and Hope Fitzgerald. "The Language Commons: An Innovative Space Supporting Second Language Acquisition." Journal of Teaching and Learning with Technology 8, no. 1 (2019): 33-41. https://doi.org/10.14434/jotlt.v8i1.26741.

Griffiths, Carol, and Rebecca L. Oxford. "The Twenty-First Century Landscape of Language Learning Strategies: Introduction to This Special Issue." System 43, no. 1 (2014): 1-10. https://doi.org/10.1016/j.system.2013.12.009.

Huang, Qiang. "Learners' Perceptions of Blended Learning and the Roles and Interaction of F2f and Online Learning." ORTESOL Journal 33, no. 2013 (2016): 14-33.

Ilinawati, Ilinawati, and Sijono Sijono. "Improving Students' Speaking Motivation Using Mingle Music Technique." Journal of English Educational Study (JEES) 3, no. 1 (2020): 1-9. https://doi.org/10.31932/jees.v3i1.569.

Kivunja, Charles. "Innovative Methodologies for 21st Century Learning, Teaching and Assessment: A Convenience Sampling Investigation into the Use of Social Media Technologies in Higher Education." International Journal of Higher Education 4, no. 2 (2015): 1-26. https://doi.org/10.5430/ijhe.v4n2p1.

Lim, Matthew Toh Loy, Masitah Shahrill, Lawrence Mundia, Khairul Amilin Tengah, Abby Tan, and Mar Aswandi Mahadi. "An Alternative Approach to Teaching: Implementing a Cooperative Learning Strategy Students Team Achievement Division at the Junior College Level." Advanced Science Letters 22, no. 5-6 (2016): 1725-29. https://doi.org/10.1166/asl.2016.6748.

Liu, Chen Chung, Pin Ching Wang, and Shu Ju Diana Tai. "An Analysis of Student Engagement Patterns in Language Learning Facilitated by Web 2.0 Technologies." ReCALL 28, no. 2 (2016): 104-22. https://doi.org/10.1017/S095834401600001X.

Mahmudi, Arifka, Suci Ramadhanti Febriani, Maidatul Hasanah, Zakiyah Arifa, Universitas Islam, Negeri Maulana, Malik Ibrahim, Kota Malang, and Jawa Timur. "Classroom Management and Arabic Learning Based On Multiple Intelligences". Arabiyât 6, no. 2 (2019): 222-37.

Marasabessy, Muhammad Junaidi. "Manajemen Mutu Bertaraf World Class University (Multikasus Di Universitas Islam Negeri Maliki Malang Dan Universitas Brawijaya).” UIN Maulana Malik Ibrahim Malang, 2016.

Mastuki. "World Class University: Obsesi Atau Mimpi?" Jakarta, 2015. http://diktis.kemenag.go.id/NEW/index.php?berita=detil\&jenis=artikel\&jd=498\#.X Oh_F9IzbMy diakses pada 28 September 2020 pukul 18.30 .

Moeller, Aleidine J., and Theresa Catalano. "Foreign Language Teaching and Learning." International Encyclopedia of the Social \& Behavioral Sciences: Second Edition, 2015, 327-32. https://doi.org/10.1016/B978-0-08-097086-8.92082-8.

Muis, Muhsin. "Bahasa Arab Di Era Digital: Eksistensi Dan Implikasi Terhadap Penguatan Ekonomi Keumatan." Jurnal Al-Fathin 3, no. 1 (2020): 64.

Muranova, Olga. "New Media and Perennial Problems in Foreign Language Learning Jurnal Al Bayan: Jurnal Jurusan Pendidikan Bahasa Arab, 13 (1): 53-72 (2021)| 70 
and Teaching." CALICO Journal 34, no. 3 (2016): 380-83. https://doi.org/10.1558/cj.32173.

Pane, Akhiril. "Urgensi Bahasa Arab Sebagai Alat Komunikasi Agama Islam" Komunikologi." KOMUNIKOLOGI 2, no. 1 (2018). http://jurnal.uinsu.ac.id/index.php/KOMUNIKOLOGI/article/view/5452.

Payne, J. Scott. "Developing L2 Productive Language Skills Online and the Strategic Use of Instructional Tools." Foreign Language Annals, no. May (2020): 1-7. https://doi.org/10.1111/flan.12457.

Pratiwi, Dienda Arum, Bambang Purwanggono, and Arfan Bakhtiar. "Kriteria World Class University Qs World Rankings.” Industrial Engineering Online Journal 6, no. 1 (2017).

Sadiku, Lorena Manaj. "The Importance of Four Skills Reading, Speaking, Writing, Listening in a Lesson Hour." European Journal of Language and Literature 1, no. 1 (2015): 29. https://doi.org/10.26417/ejls.v1i1.p29-31.

Samiril Taurus Tamaji. "Pembelajaran Bahasa Arab Dengan Pendekatan Contekstual Teacing and Learning (CTL)." In Universitas Negeri Malang, 46. Malang: Universitas Negeri Malang, 2019.

Sauri, Sofyan. "Sejarah Perkembangan Bahasa Arab Dan Lembaga Islam." INSANCITA: Journal of Islamic Studies in Indonesia and Southeast Asia, 5, no. 1 (2020): 73-88. https://doi.org/https://doi.org/10.2121/incita-jisisea.v5i1.1332.g1159.

Setiawati, Linda. "Efektivitas Pengembangan Manajemen Pendidikan Tinggi (Studi Pada Perguruan Tinggi Negeri Di Jawa Barat Menuju World Class University)." Penelitian Pendidikan 12, no. 2 (2012): 1-15. https://doi.org/10.1245/s10434-0144122-7.

Shaleh, Agus. "Kendala Dan Solusi Kreatif Mahasiswa Dalam Belajar Bahasa, Sastra Dan Budaya Arab: Lingkungan Behavioristik Dalam Berkomunakasi Bahasa Arab Di STAI Syaichona Moh. Cholil Bangkalan." In Seminar Nasional Bahasa Arab Mahasiswa I Tahun 2017. Malang: Jurusan Sastra Arab Fakultas Sastra Universitas Negeri Malang, 2017.

Shattock, Michael. "The 'World Class' University and International Ranking Systems: What Are the Policy Implications for Governments and Institutions?" Policy Reviews in Higher Education 1, no. 1 (2017): 4-21. https://doi.org/10.1080/23322969.2016.1236669.

Song, Sooho. "Second Language Acquisition as a Mode-Switching Process: An Empirical Analysis of Korean Learners of English." Second Language Acquisition as a Mode-Switching Process: An Empirical Analysis of Korean Learners of English, 2017, 1-151. https://doi.org/10.1057/978-1-137-52436-2.

Syairi, Khairi Abu. "Pengembangan Bahan Ajar Bahasa Arab." Dinamika Ilmu 13, no. 1 (2013): $51-66$. http://journal.iain- 
samarinda.ac.id/index.php/dinamika_ilmu/article/view/65.

Taskiran, Ayse, Eylem Koral Gumusoglu, and Belgin Aydin. "Fostering Foreign Language Learning with Twitter: Reflections from English Learners." Turkish Online Journal of Distance Education 19, no. 1 (2018): 100-116. https://doi.org/10.17718/tojde.382734.

Ummi, Hikmah Uswatun, and Indrya Mulyaningsih. "Penerapan Teori Pembelajaran Bahasa Arab Di IAIN Syekh Nurjati Cirebon." Journal Indonesian Language Education and Literature 1, no. 2 (2016): 207-20. http://www.syekhnurjati.ac.id/jurnal/index.php/jeill/\%0APEMBELAJARAN.

Usoh, E. J., D. Ratu, A. Manongko, J. Taroreh, and G. Preston. "Strategic Planning towards a World-Class University." IOP Conference Series: Materials Science and Engineering 306, no. 1 (2018). https://doi.org/10.1088/1757-899X/306/1/012035.

Wangsadanureja, Miftah. "Peran Bahasa Arab Dalam Memahami Pendidikan Agama Islam Dengan Pendekatan Berfikir Knowledge or Certainty." Jurnal Pendidikan Islam 8, no. https://journal.uhamka.ac.id/index.php/jpi/article/view/299\%0A

Yahya, Yuangga Kurnia. "Usaha Bahasa Arab Dalam Menghadapi Era Globalisasi." Konferensi Nasional Bahasa Arab 3, 2017, 38-48.

Yin, Robert K. "Robert K. Yin Case Study Research Design and Methods, Third Edition, Applied Social Research Methods Series, Vol 5 2002.Pdf," 2003. 